\title{
Spermiogenesis and ultrastructure of the spermatozoon of the trypanorhynch cestode Aporhynchus menezesi (Aporhynchidae), a parasite of the velvet belly lanternshark Etmopterus spinax (Elasmobranchii: Etmopteridae)
}

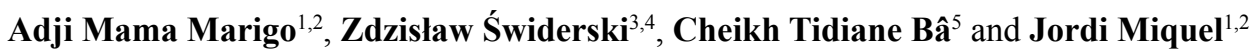 \\ ${ }^{1}$ Laboratori de Parasitologia, Departament de Microbiologia i Parasitologia Sanitàries, Facultat de Farmàcia, Universitat de \\ Barcelona, Av. Joan XXIII, sn, E-08028 Barcelona, Spain; \\ ${ }^{2}$ Institut de Recerca de la Biodiversitat, Facultat de Biologia, Universitat de Barcelona, Av. Diagonal, 645, E-08028 Barcelona, \\ Spain; \\ ${ }^{3}$ W. Stefański Institute of Parasitology, Polish Academy of Sciences, 51/55 Twarda Street, Warsaw, Poland; \\ ${ }^{4}$ Department of General Biology and Parasitology, Warsaw Medical University, Warsaw, Poland; \\ ${ }^{5}$ Laboratoire de Parasitologie, Département de Biologie Animale, Faculté des Sciences, Université Cheikh Anta Diop de Dakar, \\ Dakar, Senegal
}

\begin{abstract}
Spermiogenesis and the ultrastructural organisation of the spermatozoon of the trypanorhynch cestode Aporhynchus menezesi Noever, Caira, Kuchta et Desjardins, 2010 are described by means of transmission electron microscopy. Type I spermiogenesis of $A$. menezesi starts with the formation of a differentiation zone containing two centrioles separated by an intercentriolar body constituted by five electron-dense plates. Each centriole gives rise to a free flagellum, which grows at an angle of $90^{\circ}$ in relation to a median cytoplasmic process. The nucleus and cortical microtubules elongate along the spermatid body. Later, both flagella rotate and fuse with the median cytoplasmic process. At the final stage of spermiogenesis, the young spermatozoon is detached from the residual cytoplasm by a narrowing of the ring of arched membranes. The mature spermatozoon is a long and filiform cell, tapered at both ends, lacking mitochondria. It is characterized by the presence of two axonemes of the 9+' 1 ' trepaxonematan pattern, the absence of crested bodies, the presence of parallel cortical microtubules and nucleus. This pattern corresponds to the type I spermatozoon of the eucestodes. The anterior extremity of the spermatozoon is characterized by the presence of an arc-like row of up to seven parallel cortical microtubules that partially surrounds the first axoneme. These anterior cortical microtubules are thicker than the posterior microtubules and, consequently, the sperm cell of A. menezesi exhibits two types of cortical microtubules. Another interesting aspect is the presence of $\alpha$-glycogen rosettes. This spermatological pattern is similar to that observed in the spathebothriidean and diphyllobothriidean cestodes.
\end{abstract}

Keywords: Aporhynchus menezesi, Cestoda, Trypanorhyncha, Gymnorhynchoidea, Aporhynchidae, ultrastructure, spermiogenesis, spermatozoon

Trypanorhynch cestodes are amongst the most common metazoan parasites of marine fish. Whilst adults are typically found in the stomach and intestine of sharks and rays, larval forms infect a wide variety of marine invertebrates and teleosts. This order includes marine polyzoic cestodes, which are unique in the possession of a rhyncheal apparatus. The Trypanorhyncha Diesing, 1863 is characterized by a scolex bearing two or four bothria (Jones et al. 2004) and a tentacular apparatus consisting of four retractile tentacles adorned with hooks as extensions of tentacle sheaths that are attached to four bulbs (Dollfus 1942). This complex attachment appara- tus is unique within the cestodes, and provides a strong synapomorphy that supports the monophyly of this order (see Palm et al. 2009).

Palm (2004) recognized 254 trypanorhynch species. However, in the last years, several authors have added 25 more species to the order (see Palm et al. 2009, Noever et al. 2010). Thus, a total of 279 trypanorhynch species can be considered valid, with additional species and genera being described every year.

All these species were previously inserted into four different superfamilies (see Campbell and Beveridge 1994), namely Homeacanthoidea Dollfus, 1942, Hetera- 
canthoidea Dollfus, 1942, Otobothrioidea Dollfus, 1942, and Poecilacanthoidea Dollfus, 1942. However, considering characters other than the patterns of tentacle hook organisation, Palm (2004) reorganized the order Trypanorhyncha into five superfamilies and created a new family (Progrillotiidae Palm, 2004). These superfamilies are the Tentacularioidea Poche, 1926, Gymnorhynchoidea Dollfus, 1935, Lacisthorhynchoidea Guiart, 1927, Otobothrioidea and Eutetrarhynchoidea Guiart, 1927. The cladistic analysis also presented by Palm (2004) and based on a matrix of morphological data shows the Trypanorhyncha as a polyphyletic order. In this sense, the molecular study of Palm et al. (2009) is congruent with this condition and demonstrates that the trypanorhynchs consist of two well-supported major clades. The first clade groups the superfamily Eutetrarhynchoidea and the Tentacularioidea while the second clade groups the Gymnorhynchoidea, the Lacistorhynchoidea and the Otobothrioidea.

Although the genus Aporhynchus Nybelin, 1918 was first placed within the family Gilquiniidae Dollfus, 1942 by Campbell and Beveridge (1994), recently this genus has been attributed to the Aporhynchidae Poche, 1926 by Palm (2004). Thus, the family Aporhynchidae contains only the genus Aporhynchus. However, according to Beveridge et al. (1999) a cladistic analysis of the trypanorhynch genera revealed a close relationship between the genera Aporhynchus, Gilquinia Guiart, 1927 and Deanicola Beveridge, 1990. Therefore the precise phylogenetic position of gilquiniid and aporhynchid species is still unclear.

In the last years the ultrastructural data on spermatology have been demonstrated to be useful to interpret the relationships of the Platyhelminthes (Euzet et al. 1981, Justine 1991, 1998, 2001, Bâ and Marchand 1995, Levron et al. 2010) and they were incorporated with morphological characters and molecular data for a better interpretation of Platyhelminthes relationships (Hoberg et al. 1997, Olson et al. 2001). There is a large amount of ultrastructural studies on eucestode species, but most of them refer to species belonging to the order Cyclophyllidea van Beneden in Braun, 1900 (see Justine 1998, 2001, Levron et al. 2010). In contrast, considering the order Trypanorhyncha, data on the ultrastructural characters of spermatozoa or spermiogenesis refer only to two lacistorhynchiids, namely Lacistorhynchus tenuis (van Beneden, 1858) and Grillotia erinaceus (van Beneden, 1858), and two eutetrarhynchids, namely Dollfusiella spinulifera (Beveridge et Jones, 2000) and Parachristianella trygonis Dollfus, 1946 (see Świderski 1976, 1994, McKerr 1985, Miquel and Świderski 2006, Miquel et al. 2007a). Data concerning $L$. tenuis were presented in two conferences by Świderski $(1976,1994)$ while data on $G$. erinaceus were included in the unpublished $\mathrm{PhD}$ thesis of McKerr (1985). With respect to the eutetrarhynchids, Miquel and Świderski (2006) and Miquel et al. (2007a) only describe the ultrastructural organisation of the mature spermatozoon.

The aim of the present study is to describe the ultrastructure of spermiogenesis and of the mature spermatozoon of a gymnorhynchoidean trypanorhynch, Aporhynchus menezesi Noever, Caira, Kuchta et Desjardins, 2010, thus providing the first ultrastructural study on this superfamily and increasing the available spermatological data concerning the Trypanorhyncha.

\section{MATERIALS AND METHODS}

Live adult specimens of $A$. menezesi were collected from the spiral valve of a naturally infected velvet belly lanternshark, $E t$ mopterus spinax (L.) (Elasmobranchii, Etmopteridae) captured off the Faial Island $\left(38^{\circ} 31^{\prime} \mathrm{N}, 28^{\circ} 37^{\prime} \mathrm{W}\right)$ (Azores Archipelago, Portugal).

Live cestodes were first placed in a $0.9 \% \mathrm{NaCl}$ solution and the mature proglottids were fixed in cold $\left(4{ }^{\circ} \mathrm{C}\right) 2.5 \%$ glutaraldehyde in a $0.1 \mathrm{M}$ sodium cacodylate buffer at $\mathrm{pH} 7.2$ for a minimum of $2 \mathrm{~h}$, rinsed in a $0.1 \mathrm{M}$ sodium cacodylate buffer at $\mathrm{pH} 7.2$, postfixed in cold $\left(4^{\circ} \mathrm{C}\right) 1 \%$ osmium tetroxide in the same buffer for $1 \mathrm{~h}$, rinsed in a $0.1 \mathrm{M}$ sodium cacodylate buffer at $\mathrm{pH}$ 7.2, dehydrated in an ethanol series and propylene oxide, and finally embedded in Spurr's resin. Ultrathin sections were obtained using a Reichert-Jung Ultracut E ultramicrotome, placed on copper grids and double-stained with uranyl acetate and lead citrate (Reynolds 1963). Ultrathin sections were examined using a JEOL 1010 TEM operated at an accelerating voltage of $80 \mathrm{kV}$.

The Thiéry (1967) technique was used for proving the presence of glycogen particles. Gold grids were treated in periodic acid, thiocarbohydrazide, and silver proteinate (PA-TCH-SP) as follows: $30 \mathrm{~min}$ in $10 \% \mathrm{PA}$, rinsed in distilled water, $24 \mathrm{~h}$ in $\mathrm{TCH}$, rinsed in acetic solutions and distilled water, $30 \mathrm{~min}$ in $1 \%$ $\mathrm{SP}$ in the dark, and rinsed in distilled water.

\section{RESULTS}

\section{Spermiogenesis}

The sperm differentiation or spermiogenesis in A. menezesi starts with the formation of a rosette containing numerous peripheral spermatids attached to the central cytophore (Fig. 1). The cytoplasm of the spermatids contains a nucleus and a large, densely packed accumulation of mitochondria (Fig. 1). Later the plasma membrane of the spermatid cluster invaginates and forms the differentiation zone situated on the periphery of each spermatid (Figs. 2, 3, 9a). This is a conical protrusion bordered by cortical microtubules. It contains two centrioles interconnected by an intercentriolar body and associated with striated rootlets (Figs. 2-4, 9a). Each centriole gives rise to a flagellum, which grows externally (Figs. 3, 9b, c). The intercentriolar body is composed of five plates: a central thick electron-dense plate, one thin electron-dense plate on each side of the central plate and one thicker electrondense plate externally on each side of the thin plates (Fig. 4). Cortical microtubules lengthen along a grow- 

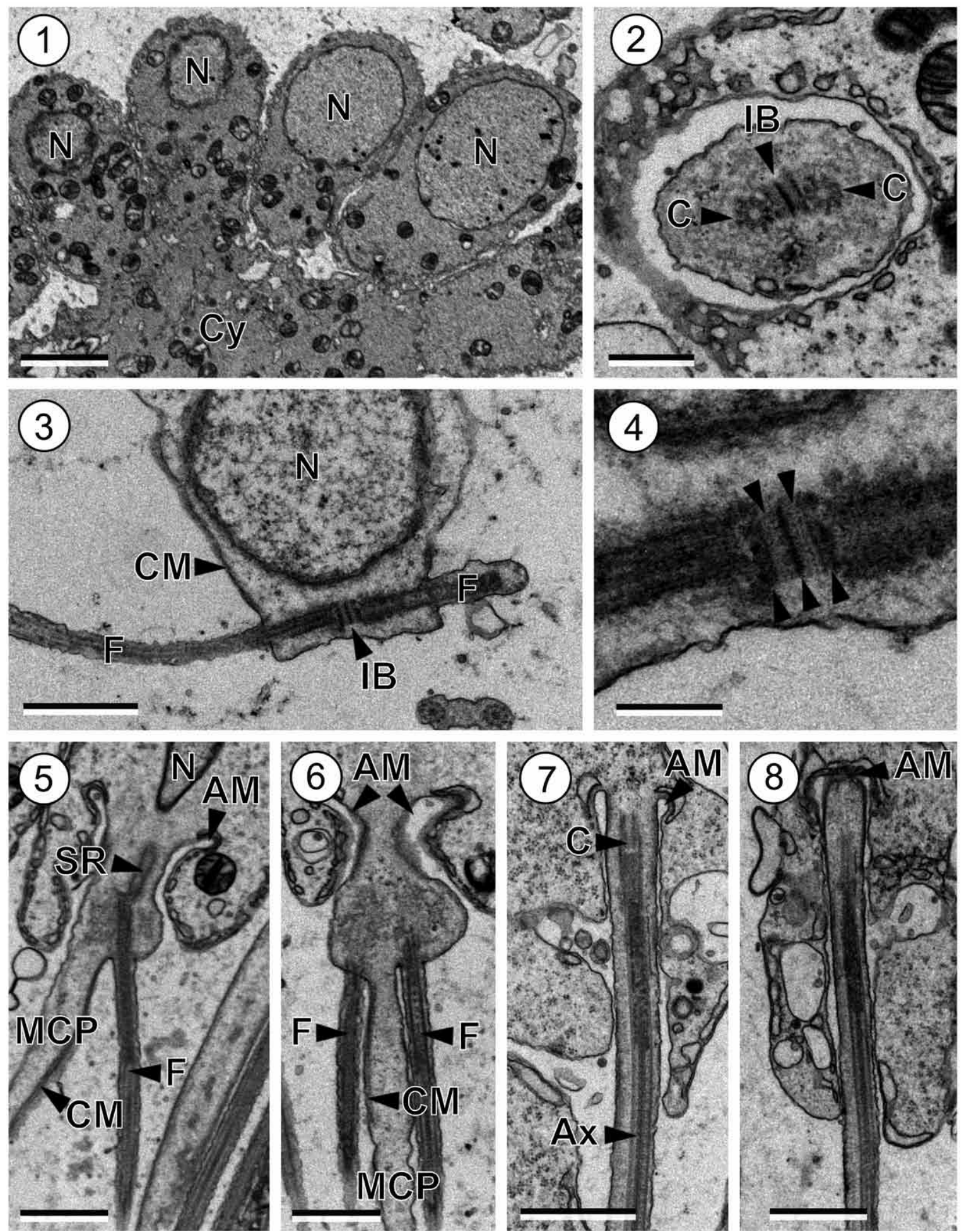

Figs. 1-8. Spermiogenesis of Aporhynchus menezesi. Fig. 1. Rosette showing numerous peripheral spermatids attached to the central cytophore (Cy). N - nucleus. Fig. 2. Cross-section of the zone of differentiation showing the two centrioles (C) and the intercentriolar body (IB). Fig. 3. Longitudinal section of a zone of differentiation showing the two flagella (F), the nucleus $(\mathrm{N})$ and the intercentriolar body (IB). CM - cortical microtubules. Fig. 4. Detail of the intercentriolar body showing five electron-dense plates. Fig. 5. Longitudinal section of a spermatid during flagellar rotation. AM - arched membranes; $\mathrm{CM}$ - cortical microtubules; F - flagellum; MCP - median cytoplasmic process; $\mathrm{N}$ - nucleus; SR - striated roots. Fig. 6. Longitudinal section of a spermatid showing the two parallel flagella (F) before the proximodistal fusion. AM - arched membranes; CM - cortical microtubules; MCP - median cytoplasmic process. Fig. 7. Longitudinal section of a spermatid after the proximodistal fusion, showing one axoneme (Ax). AM - arched membrane; $\mathrm{C}$ - centriole. Fig. 8. Final stage of the spermiogenesis showing the strangulation of the ring of arched membranes (AM). Scale bars: Fig. $1=2.5 \mu \mathrm{m}$; Fig. $2=0.5 \mu \mathrm{m}$; Figs. $3,5-8=1 \mu \mathrm{m}$; Fig. $4=0.25 \mu \mathrm{m}$. 
(a)

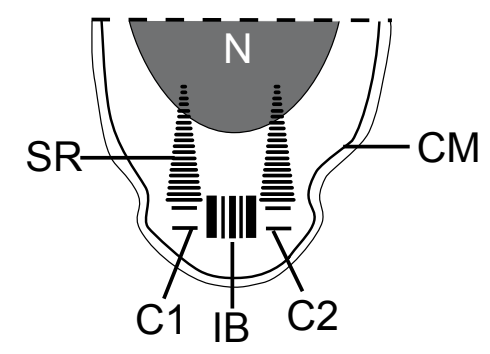

(b)

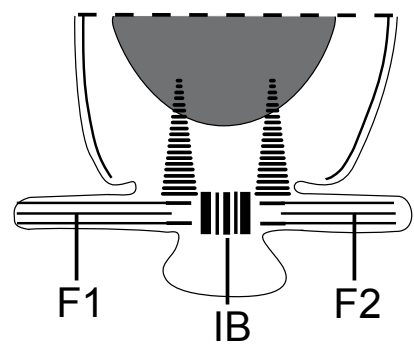

(C)

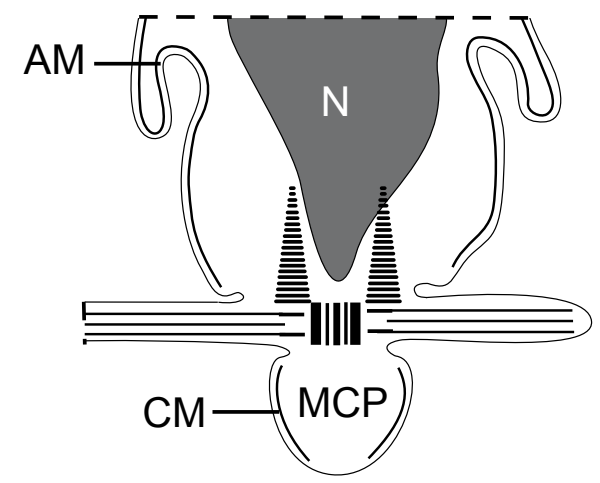

(f)

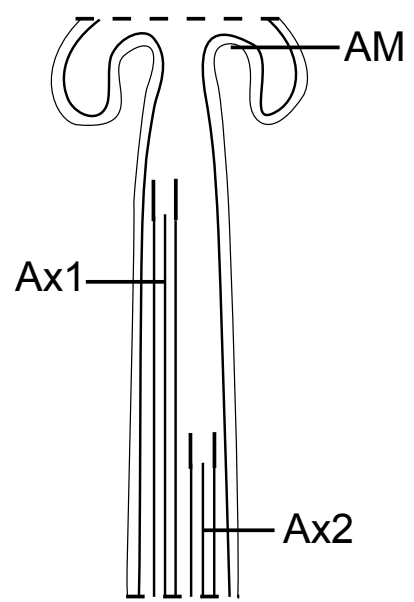

Fig. 9(a-f). Schematic drawing showing the main stages of spermiogenesis of Aporhynchus menezesi. AM - arched membranes; $\mathrm{Ax} 1$ - axoneme 1; Ax2 - axoneme 2; C1 - centriole 1; C2 - centriole 2; CM - cortical microtubules; F1 - flagellum 1; F2 - flagellum 2; IB - intercentriolar body; $\mathrm{MCP}$ - median cytoplasmic process; $\mathrm{N}$ - nucleus; $\mathrm{SR}$ - striated rootlets.

ing median cytoplasmic process. The nucleus initiates its elongation and the flagella undergo a $90^{\circ}$ rotation (Figs. 3, $5,6,9 \mathrm{c}, \mathrm{d})$ becoming parallel to the median cytoplasmic process (Figs. 6, 9d). The flagella rotation is followed by their proximodistal fusion with the median cytoplasmic process (Figs. 7, 9e). Finally, the ring of arching membranes is strangled and the young spermatozoon is detached from the residual cytoplasm (Figs. 8, 9f).

\section{Spermatozoon}

The observation of numerous longitudinal and crosssections has enabled us to establish four (I-IV) different regions in the mature spermatozoon of $A$. menezesi. It is a long filiform cell, tapered at both ends, which lacks mitochondria and crested body. The cytoplasm contains two axonemes of different lengths of the 9+' 1 ' pattern of trepaxonematan Platyhelminthes, a parallel nucleus, $\alpha$-glycogen rosettes and two types of cortical microtubules: the first type refers to microtubules that exhibit an opaque electron-dense centre and the second type refers to microtubules that exhibit a hollow centre.

Region I (Figs. 10-14, 25I) constitutes the anterior extremity of the spermatozoon. The anterior tip contains four to seven thick and electron-dense cortical microtubules (Figs. 10, 11) that later form a semi-arc beneath the plasma membrane partially surrounding the first centriole (Figs. 12, 13) and also the proximal areas of the first axoneme (Fig. 14).

Region II (Figs. 15-18, 24, 25II) constitutes the prenuclear area of the spermatozoon containing two axonemes. At the end of region I, the semicircle of electron-dense cortical microtubules is interrupted by scattered tubular elements (Fig. 15), indicating the appearance of the second axoneme. Later the second centriole emerges, mate- 

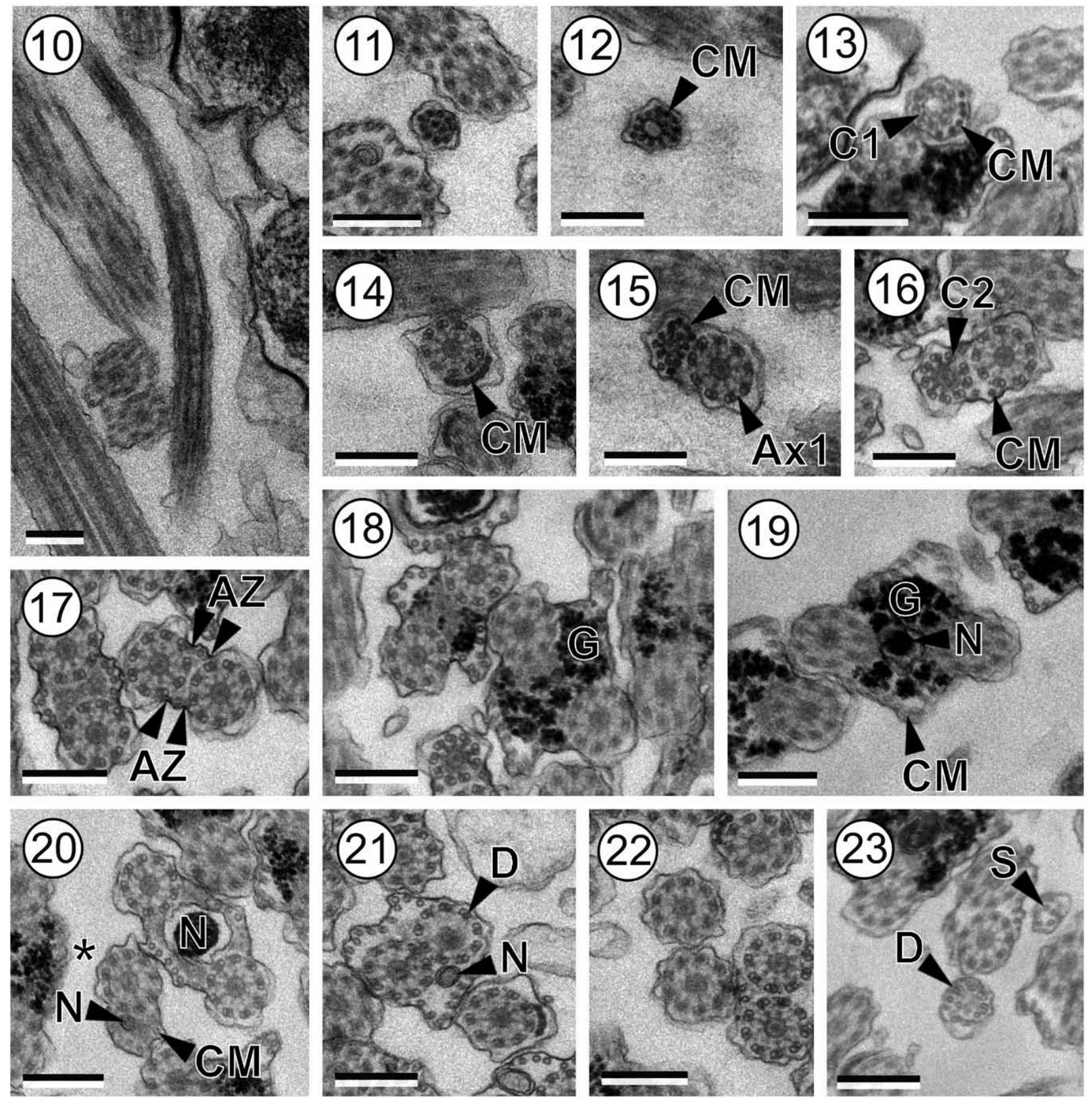

Figs. 10-23. Mature spermatozoon of Aporhynchus menezesi. Fig. 10. Longitudinal section of Region I near the anterior spermatozoon extremity. Figs. 11, 12. Cross-sections of the anterior part of Region I showing the electron-dense microtubules (CM). Fig. 13. Crosssection showing the appearance of the first centriole (C1). CM - cortical microtubules. Fig. 14. Cross-section of Region I at the level of the first axoneme showing the arc-like row of electron-dense cortical microtubules (CM). Figs. 15, 16. Cross-sections of anterior areas of Region II showing the first axoneme (Ax1) and the appearance of the second centriole (C2). CM - cortical microtubules. Fig. 17. Cross-section of Region II illustrating the presence of two pairs of attachment zones (AZ). Fig. 18. Cross-sections of Region II showing the appearance of granules of glycogen $(\mathrm{G})$. Fig. 19. Cross-section of Region III showing the nucleus $(\mathrm{N})$. CM - cortical microtubules; G - granules of glycogen. Fig. 20. Micrograph of the nuclear area showing a cross-section located before and another cross-section located after $\left({ }^{*}\right)$ the disorganisation of one of the axonemes. $\mathrm{CM}$ - cortical microtubules; $\mathrm{N}$ - nucleus. Fig. 21. Crosssection of Region III at the beginning of the disappearance of the central core of one of the axonemes. D - doublets; $\mathrm{N}$ - nucleus. Fig. 22. Cross-sections of Region IV showing the axoneme surrounded by the plasma membrane. Fig. 23. Cross-sections of Region IV near the posterior spermatozoon extremity. D - doublets; $\mathrm{S}$ - singlets. Scale bars: Fig. $10=0.5 \mu \mathrm{m}$; Figs. $11-23=0.25 \mu \mathrm{m}$. 


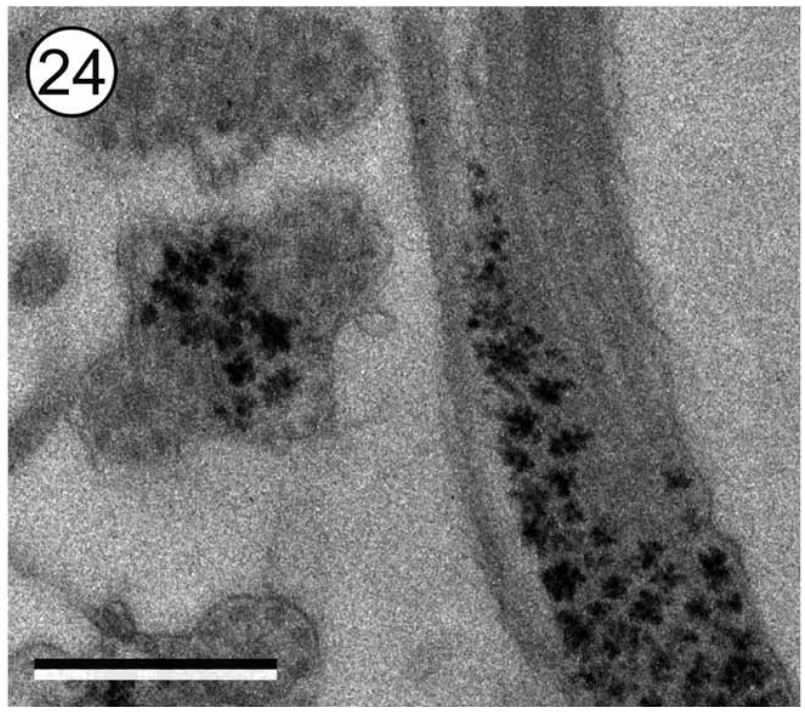

Fig. 24. Cross- and longitudinal sections of the mature spermatozoon of Aporhynchus menezesi showing rosettes of $\alpha$-glycogen evidenced by Thiéry staining. Scale bar $=0.5 \mu \mathrm{m}$.

rialized by the appearance of nine centriolar doublets in the cytoplasm (Fig. 16). At this level the presence of the hollow-centre cortical microtubules is observed (Figs. 17, 18). They are distributed in two opposite fields and their quantity progressively increases (Figs. 17, 18). A narrow cytoplasmic bridge connects the axonemes in some spermatozoa (Fig. 17) and the attachment zones are also observed at this stage (Fig. 17). Later, two opposite rows of cortical microtubules are situated under the plasma membrane (Figs. 17, 18). The granules of glycogen, in the form of $\alpha$-glycogen rosettes, appear progressively as the spermatozoon section enlarges (Figs. 18, 24).

Region III (Figs. 19-21, 25III) constitutes the nuclear area of the spermatozoon. In cross-sections, the nucleus is oval to circular, situated centrally between the axonemes (Figs. 19, 20). It contains strands of fine fibrillar material and enlarges gradually towards the posterior end. In the first part, this region also encloses two axonemes, cortical microtubules, and a large amount of glycogen (Fig. 19). Later the presence of glycogen gradually decreases (Fig. 20). The nuclear region is the area of the spermatozoon that contains the maximum number of cortical microtubules arranged in two parallel fields (Figs. 19-21). Subsequently, one of the axonemes loses its central element (Fig. 21); doublets disorganize and transform into singlets, which finally disappear. The posterior part of the nuclear region contains only one axoneme, the nucleus and some cortical microtubules (Fig. 20).

Region IV (Figs. 22, 23, 25IV) constitutes the postnuclear area of the spermatozoon. This is the posterior end and contains the axoneme surrounded by cytoplasmic membrane (Fig. 22). This single axoneme later disorganizes and disappears at the level of the posterior tip of the sperm cell (Fig. 23).

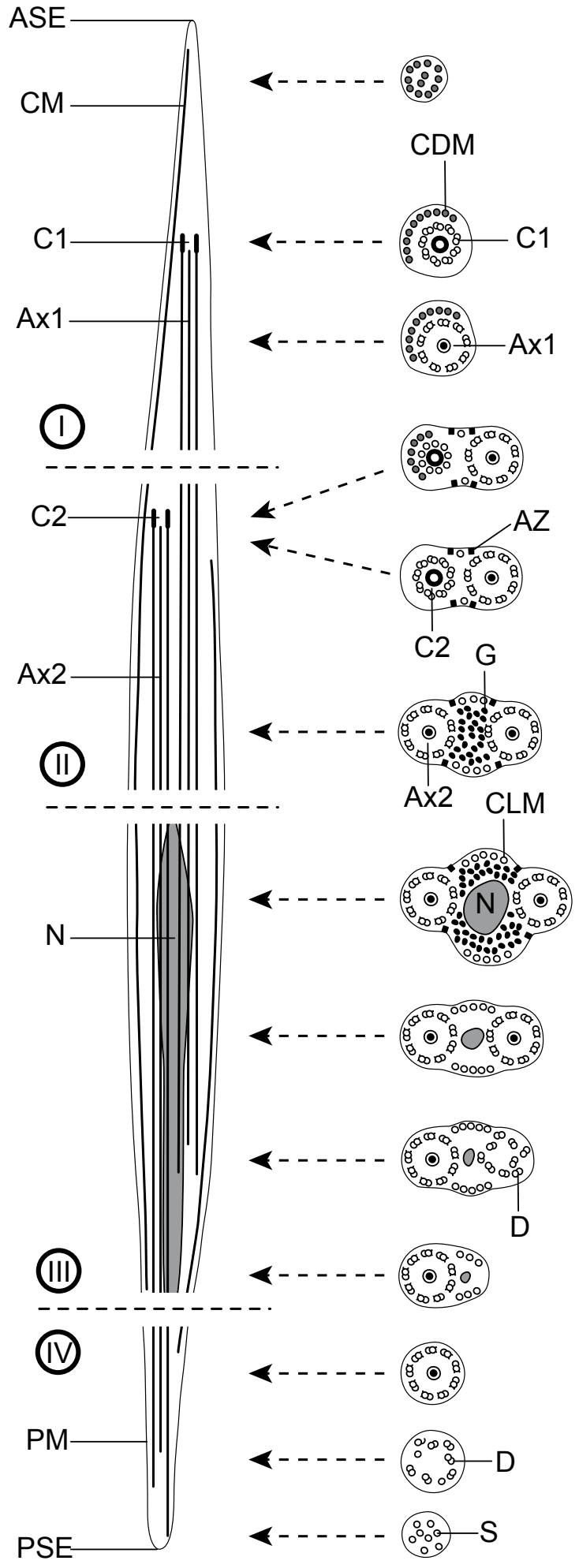

Fig. 25(I-IV). Schematic drawing showing the ultrastructural organisation of the mature spermatozoon of Aporhynchus menezesi. ASE - anterior spermatozoon extremity; Ax1 - axoneme 1; Ax2 - axoneme 2; AZ - attachment zone; $\mathrm{C} 1$ - centriole 1; $\mathrm{C} 2$ - centriole 2; CDM - electron-dense cortical microtubules; CLM - electron-lucent cortical microtubules; D - doublets; $\mathrm{G}$ - $\alpha$-glycogen rosette; $\mathrm{N}$ - nucleus; $\mathrm{PM}$ - plasma membrane; $\mathrm{PSE}$ - posterior spermatozoon extremity; $\mathrm{S}$ - singlets. 
Table 1. Spermatological characters in trypanorhynch cestodes.

\begin{tabular}{|c|c|c|c|c|c|c|c|c|c|c|c|c|c|}
\hline \multirow[b]{2}{*}{ Superfamily, family and species (reference) } & \multicolumn{5}{|c|}{ Spermiogenesis } & \multicolumn{8}{|c|}{ Spermatozoon } \\
\hline & Type & FR & $\mathrm{PF}$ & IB & SR & Type & ASE & $\mathrm{AC}$ & $\mathrm{CB}$ & ArcCM & $\mathrm{AZ}$ & G & PSE \\
\hline $\begin{array}{l}\text { Eutetrarhynchoidea, Eutetrarhynchidae } \\
\text { Dollfusiella spinulifera (Miquel and Swiderski } \\
\text { 2006) } \\
\text { Parachristianella trygonis (Miquel et al. 2007a) }\end{array}$ & & & & & & $\begin{array}{l}\text { I } \\
\text { I }\end{array}$ & $\begin{array}{l}\mathrm{CM} \\
\mathrm{CM}\end{array}$ & - & $\begin{array}{l}- \\
-\end{array}$ & $\begin{array}{l}10 \\
10\end{array}$ & $\begin{array}{l}+ \\
+\end{array}$ & $\begin{array}{l}\alpha, \beta \\
\alpha, \beta\end{array}$ & $\begin{array}{l}1 \mathrm{Ax} \\
1 \mathrm{Ax}\end{array}$ \\
\hline $\begin{array}{l}\text { Lacistorhynchoidea, Lacistorhynchidae } \\
\text { Lacistorhynchus tenuis (Świderski 1976, 1994) } \\
\text { Grillotia erinaceus (McKerr 1985) }\end{array}$ & $\begin{array}{l}\text { I } \\
\text { I }\end{array}$ & $\begin{array}{l}+ \\
+\end{array}$ & $\begin{array}{l}+ \\
+\end{array}$ & $\begin{array}{l}5 \\
7\end{array}$ & $\begin{array}{l}+ \\
+\end{array}$ & & & - & & & & $\begin{array}{c}\beta \\
\alpha, \beta\end{array}$ & \\
\hline $\begin{array}{l}\text { Gymnorhynchoidea, Aporhynchidae } \\
\text { Aporhynchus menezesi (present study) }\end{array}$ & I & + & + & 5 & + & I & $\mathrm{CM}$ & - & - & 7 & + & $\alpha$ & $1 \mathrm{Ax}$ \\
\hline
\end{tabular}

$\mathrm{AC}$ - apical cone; ArcCm - number of cortical microtubules in the arc-like row; ASE - anterior spermatozoon extremity; Ax - axoneme; AZ - attachment zone; CB - crested body; CM - cortical microtubules; FR - flagellar rotation; G - type of glycogen; IB - number of plates of the intercentriolar body; PF - proximodistal fusion; PSE - posterior spermatozoon extremity; SR - striated rootlets; +/- presence/absence of character; no marked characters correspond to unknown data or requiring confirmation. Spermiogenesis and spermatozoa types are considered according to Bâ and Marchand (1995) and Levron et al. (2010), respectively.

\section{DISCUSSION}

\section{Spermiogenesis}

The process of spermiogenesis in Aporhynchus menezesi includes the presence of two centrioles, an intercentriolar body and two striated rootlets in the differentiation zone, flagellar rotation and proximodistal fusion. Therefore it corresponds to the basic pattern of the pseudophyllidean type of spermiogenesis described by Świderski (1986) or the type I of Bâ and Marchand (1995). Type I spermiogenesis has been reported in species belonging to the orders Spathebothriidea Wardle et McLeod, 1952, Diphyllobothriidea Kuchta, Scholz, Brabec et Bray, 2008, Bothriocephalidea Kuchta, Scholz, Brabec et Bray, 2008, Diphyllidea van Beneden in Carus, 1863, Trypanorhyncha, Tetraphyllidea Carus, 1863, and Proteocephalidea Mola, 1928 (see the reviews of Justine 1998, 2001, Bruňanská 2010, Levron et al. 2010) and was considered to be a plesiomorphic process in the eucestodes by Justine (1998). All the studied trypanorhynch cestodes exhibit this type of spermiogenesis. However, the number of plates (five or seven) forming the intercentriolar body is variable in these species (see Table 1). In fact, the number of intercentriolar body plates is seven in $G$. erinaceus (Lacistorhynchoidea) (see McKerr 1985) and five in the remaining studied species, namely $L$. tenuis (Lacistorhynchoidea) (see Świderski 1994) and A. menezesi (Gymnorhynchoidea) (present study).

The number of intercentriolar plates has been used in a recent phylogenetic analysis of the Eucestoda inferred both from ultrastructural data alone and from a combination of ultrastructural and morphological data (Levron et al. 2010). Within the Eucestoda, although the intercentriolar body is absent from the Tetrabothriidea and Cyclophyllidea, it is present as a single-plate body in the Lecanicephalidea Wardle et McLeod, 1952 and Proteocephalidea and as a multiplate body in the remaining orders. However, it is interesting to remark the dual condition of mesocestoidids, presenting both single and multiplate intercentriolar bodies (see Miquel et al. 1999, 2007b).
Although the type of spermiogenesis in trypanorhynch cestodes is similar to that described in the caryophyllideans, in the spathebothriideans and in certain species of the former Pseudophyllidea Carus, 1863 (see Bruňanská et al. 2001, 2006, Levron et al. 2005, 2006a, b, 2009, Bruňanská and Poddubnaya 2006, 2010, Miquel et al. 2008, Bruňanská 2009, Šípková et al. 2010), the electrondense material appearing in initial stages of spermiogenesis in the apical region of the differentiation zone is not observed in $A$. menezesi as in the other trypanorhynch species studied to date (McKerr 1985, Świderski 1994).

\section{Spermatozoon}

No evident differences were found in the ultrastructural organisation of the spermatozoon of $A$. menezesi in comparison with the other trypanorhynch species studied to date (Świderski 1976, McKerr 1985, Miquel and Świderski 2006, Miquel et al. 2007a). The spermatozoon possesses two axonemes of the 9+ ' 1 ' trepaxonematan pattern (Ehlers 1984) of different lengths, a parallel nucleus, parallel cortical microtubules and lacks crested body, periaxonemal sheath and transverse intracytoplasmic walls. This type of sperm's schema corresponds to the type I of Levron et al. (2010) and is found in species of the orders Spathebothriidea, Diphyllobothriidea, Haplobothriidea Joyeux et Baer, 1961 and Trypanorhyncha.

As in Dollfusiella spinulifera and Parachristianella trygonis, the anterior extremity of the spermatozoon of A. menezesi contains a single axoneme partially surrounded by an arc-like layer of submembranous cortical microtubules parallel to the hypothetical spermatozoon axis. Moreover, the cortical microtubules that constitute this arc-like layer are thick and their centre is electron-dense, while posterior cortical microtubules present a hollow centre. Consequently, two types of cortical microtubules can be considered in the spermatozoon of these trypanorhynchs (Miquel and Świderski 2006, Miquel et al. 2007a, Levron et al. 2010).

This arc-like row of cortical microtubules has been observed in the anterior part of the spermatozoon of numer- 
ous eucestodes, but there is variability in their aspect and number. In trypanorhynch species the number of cortical microtubules forming this arc-like layer varies from seven to ten microtubules. Thus, D. spinulifera and P. trygonis present an arc-like row constituted by ten microtubules (Miquel and Świderski 2006, Miquel et al. 2007a) whereas in $A$. menezesi the maximal number is seven (see Table 1).

Anterior spermatozoon extremities showing a similar arrangement of cortical microtubules describing an arclike layer were found in the Caryophyllidea (Gamil 2008, Bruňanská 2009), Spathebothriidea (Bruňanská et al. 2006, Bruňanská and Poddubnaya 2010), Diphyllobothriidea (Justine 1986, Levron et al 2006a, 2009), Bothriocephalidea (Bruňanská et al. 2002, Levron et al. 2006c, Bâ et al. 2007), Diphyllidea (Azzouz-Draoui and MokhtarMaamouri 1986/88), Tetraphyllidea (Mokhtar-Maamouri and Świderski 1975, 1976, Mokhtar-Maamouri 1979, 1982, Mahendrasingam et al. 1989), Proteocephalidea (Bruňanská et al. 2003a, b, 2004a, b), and in the mesocestoidid cyclophyllideans (Miquel et al. 1999, 2007b). However, the arc-like layer of thicker cortical microtubules described in the trypanorhynchs also occurs only in the former pseudophyllideans, in the tetraphyllideans, in the proteocephalideans and in the mesocestoidids.

However, particular aspects of this character are described in the anterior spermatozoon extremity of four bothriocephalidean cestodes. These are Bothriocephalus scorpii (Muller, 1781), in which Levron et al. (2006b) describe up to three arc-like layers of cortical microtubules, Triaenophorus nodulosus Pallas, 1791 (see Levron et al. 2005), which possesses a layer of microtubules in a spiral pattern forming one and a half open circles around the axoneme, and Bothriocephalus clavibothrium Ariola, 1899 and Parabothriocephalus gracilis Yamaguti, 1934 (see Świderski and Mokhtar-Maamouri 1980, Śípková et al. 2010), which present a complete ring of cortical microtubules. Moreover, in the Proteocephalidea, two additional species, namely Nomimoscolex sp. and Sandonella sandoni (Lynsdale, 1960), possess two arc-like layers of cortical microtubules (see Bâ and Marchand 1994, Sène et al. 1997).

The presence of crest-like body or bodies in the anterior spermatozoon extremity has been postulated as a synapomorphy for the eucestodes (Bâ and Marchand 1995). In contrast to bothriocephalideans, tetraphyllideans, proteocephalideans, tetrabothriideans and cyclophyllideans, no crested body is present in the spermatozoon of caryophyllideans, spathebothriideans, diphyllobothriideans and haplobothriideans (see Levron et al. 2010) as occurs in all the trypanorhynchs studied to date (see Table 1). Thus, the present work confirms the absence of this structure in the sperm cell of trypanorhynch cestodes and supports the idea that crest-like bodies are a synapomorphic character only for a part of the Eucestoda and not for the whole group (Justine 1998).
The two pairs of electron-dense attachment zones, visible in the median cytoplasmic process during spermiogenesis in numerous Platyhelminthes, mark the lines of proximodistal fusion between the median cytoplasmic process and the axonemes. These attachment zones persist in mature digenean spermatozoa (e.g. Miquel et al. 2006, Quilichini et al. 2010), but they are generally absent in the mature spermatozoa of the Eucestoda. To our knowledge, in the mature sperm cell of cestodes these submembranous structures have been observed only in some diphyllobothriidean, bothriocephalidean and trypanorhynch species (Bruňanská et al. 2002, Levron et al. 2006a, b, c, 2009, Miquel and Świderski 2006, Miquel et al. 2007a). In fact, the attachment zones are also still present in the A. menezesi spermatozoon and their presence is probably a consequence of the proximodistal fusion.

According to the Thiéry's test, glycogen is present in the mature spermatozoon of $A$. menezesi. In the trypanorhynch species studied to date, the presence of two types of glycogen granules $(\alpha, \beta)$ has been demonstrated only in D. spinulifera, P. trygonis and G. erinaceus (McKerr 1985, Miquel and Świderski 2006, Miquel et al. 2007a), while in L. tenuis (Świderski 1994) and A. menezesi (present study) only one type of glycogen granules was found: the former species presents $\beta$-glycogen particles and the latter $\alpha$-glycogen rosettes.

As in D. spinulifera and P. trygonis (see Miquel and Świderski 2006, Miquel et al. 2007a), the posterior part of the spermatozoon of $A$. menezesi possesses one axoneme, which becomes disorganized towards the extremity of the cell. This pattern of posterior extremity is very common in the spermatozoon of the Eucestoda (e.g. Bruňanská et al. 2003b, Levron et al. 2005, 2009, Bruňanská 2009). However, in the eucestodes the posterior spermatozoon extremity may present different ultrastructural organisations: those formed by only a nucleus (e.g. Bruňanská et al. 2006, Levron et al. 2006a, b) or by a posterior electrondense material usually containing cortical microtubules (e.g. Miquel and Marchand 1998, Miquel et al. 2009, 2010). The latter is particularly frequent in the sperm cell of cyclophyllidean cestodes.

\section{Conclusion}

The analysis of spermatological characters of all studied trypanorhynch species allowed discussing the phyletic relationships of trypanorhynchs based on molecular data. According to Palm et al. (2009), molecular evidence demonstrates that trypanorhynchs consist of two well-supported major clades (see introduction). However, considering two lacistorhynchoideans (L. tenuis and G. erinaceus) and one gymnorhynchoidean (A. menezesi) belonging to the same clade, their spermatological characters emphasize only a few similarities (see Table 1). On the other hand, the comparison of spermatozoa of both eutetrarhynchoideans $D$. spinulifera and P. trygonis with those of the gymnorhynchoidean $A$. menezesi reveals a high degree of 
similarity between them, although they are placed in different clades. In conclusion, on the basis of the current spermatological knowledge, we are not able to explain the polyphyletic condition of the Trypanorhyncha. Subsequently, other spermatological studies focussing on species of different families are required to further elucidate this question.

Finally, it is interesting to reveal that spermatological features, specially the basic pattern of the spermatozoon, show resemblances between trypanorhynch, spatheboth- riidean and diphyllobothriidean cestodes, as recently emphasized by Levron et al. (2010) according to both spermatological and morphological characters.

Acknowledgements. This work was partially supported by funds from NSF PBI award Nos. DEB 0818696 and 0818823 to Janine N. Caira, Timothy J. Littlewood, Jean Mariaux, and Kirsten Jensen. Authors wish to thank the "Serveis Cientificotècnics" of the University of Barcelona for their support in the preparation of samples. Adji Mama Marigo benefits from a MAEC-AECID doctoral grant (2009-10 0000448124).

\section{REFERENCES}

Azzouz-Draoui N., Mokhtar-Manmouri F. 1986/88: Ultrastructure comparée de la spermiogenèse et du spermatozoïde de Echinobothrium affine Diesing, 1863 et E. harfordi Mac Vicar, 1976 (Cestoda, Diphyllidea). Bull. Soc. Sci. Nat. Tunis 18: 9-20.

BÂ C.T., BÂ A., Marchand B. 2007: Ultrastructure of the spermatozoon of Bothriocephalus claviceps (Cestoda, Pseudophyllidea): a parasite of Anguilla anguilla (Fish, Teleostei). Parasitol. Res. 101: 77-83.

BÂ C.T., Marchand B. 1994: Ultrastructure of the spermatozoon of Sandonella sandoni (Cestoda, Proteocephalidea, Sandonellinae). Invertebr. Reprod. Dev. 25: 9-17.

BÂ C.T., Marchand B. 1995: Spermiogenesis, spermatozoa and phyletic affinities in the Cestoda. Mém. Mus. Natl. Hist. Nat. 166: 87-95.

Beveridge I., Campbell R.A., Palm H.W. 1999: Preliminary cladistic analysis of genera of the cestode order Trypanorhyncha (Diesing, 1863). Syst. Parasitol. 42: 29-49.

BRUŇANSKÁ M. 2009: Spermatological characters of the caryophyllidean cestodes Khawia sinensis (Hsü, 1935), a carp parasite. Parasitol. Res. 105: 1603-1610.

BRUŇANSKÁ M. 2010: Recent insights into spermatozoa development and ultrastructure in the Eucestoda. In: T. Lejeune and P. Delvaux (Eds.), Human Spermatozoa: Maturation, Capacitation and Aabnormalities. Nova Science Publishers Inc., New York, pp. 327-354.

Bruñanská M., Nebesářová J., Scholz T. 2003b: Ultrastructure of the spermatozoon of the proteocephalidean cestode Proteocephalus torulosus (Batsch, 1786). Parasitol. Res. 89: 345-351.

Bruñanská M., NebesáŘová J., Scholz T., Fagerholm H.P. 2001: Spermiogenesis in the pseudophyllid cestode Eubothrium crassum (Bloch, 1779). Parasitol. Res. 87: 579-588.

Bruñanská M., Nebesár̆ová J., Scholz T., Fagerholm H.P. 2002: Ultrastructure of the spermatozoon of the pseudophyllidean cestode Eubothrium crassum (Bloch, 1779). Parasitol. Res. 88: 285-291.

Bruňanská M., Poddubnaya L.G. 2006: Spermiogenesis in the caryophyllidean cestode Khawia armeniaca (Cholodkovski, 1915). Parasitol. Res. 99: 449-454.

Bruñanská M., Poddubnaya L.G. 2010: Spermatological characters of the spathebothriidean tapeworm Didymobothrium rudolphii (Monticelli, 1890). Parasitol. Res. 106: 1435-1442.

Bruňanská M., Scholz T., Dezfuli B.S., Poddubnaya L.G. 2006: Spermiogenesis and sperm ultrastructure of Cyathocephalus truncatus (Pallas, 1781) Kessler, 1868 (Cestoda: Spathebothriidea). J. Parasitol. 92: 884-892.

Bruñanská M., Scholz T., Ibraheem M.H. 2004a: Ultrastructural characters of the spermatozoon of the cestode Corallobothrium solidum Fritsch, 1886 (Cestoda: Proteocephalidea), a parasite of the electric catfish Malapterurus electricus. Parasitol. Res. 94: 421-426.

Bruňanská M., Scholz T., Ibraheem M.H. 2004b: Ultrastructural particularities of the spermatozoon of the cestode Electrotaenia malopteruri (Fritsch, 1886) (Proteocephalidae: Gangesiinae), a parasites of Malapterurus electricus (Siluriformes: Malapteruridae) from the river Nile, Egypt. Parasitol. Res. 93: 114-120.

Bruňanská M., Scholz T., Nebesářová J. 2003a: Reinvestigation of the spermatozoon ultrastructure of the cestode Proteocephalus longicollis (Zeder, 1800), a parasite of salmonid fish. Parasitol. Res. 91: 357-362.

Campbell R.A., Beveridge I. 1994: Order Trypanorhyncha Diesing, 1863. In: L.F. Khalil, A. Jones and R.A. Bray (Eds.), Keys to the Cestode Parasites of Vertebrates. CAB International, Wallingford, pp. 51-148.

Dollfus R.P. 1942: Études critiques sur les Tétrarhynques du Museum de Paris. Arch. Mus. Natl. Hist. Nat. 19: 1-466.

Ehlers U. 1984: Phylogenetisches System der Plathelminthes. Verh. Naturwiss. Ver. Hamburg (NF) 27: 291-294.

Euzet L., Świderski Z., Mokhtar-Maamouri F. 1981: Ultrastructure comparée du spermatozoïde des Cestodes. Relations avec la phylogénèse. Ann. Parasitol. (Paris) 56: 247-259.

Friggens M.M., Duszynski D.W. 2005: Four new cestode species from the spiral intestine of the round stingray, Urobatis halleri, in the northern Gulf of California, Mexico. Comp. Parasitol. 72: $136-149$.

GAMIL I.S. 2008: Ultrastructural studies of the spermatogenesis and spermiogenesis of the caryophyllidean cestode Wenyonia virilis (Woodland, 1923). Parasitol. Res. 103: 777-785.

Hoberg E.P., Mariaux J., Justine J.-L., Brooks D.R., Weekes P.J. 1997: Phylogeny of the orders of the Eucestoda (Cercomeromorphae) based on comparative morphology: historical perspectives and a new working hypothesis. J. Parasitol. 83: 1128-1147.

Jones M.K., Beveridge I., Campbell R.A., Palm H.W. 2004: Terminology of the sucker-like organs of the scolex of trypanorhynch cestodes. Syst. Parasitol. 59: 121-126.

Justine J.-L. 1986: Ultrastructure of the spermatozoon of the cestode Duthiersia fimbriata (Pseudophyllidea, Diphyllobothriidae). Can. J. Zool. 64: 1545-1548.

Justine J.-L. 1991: Phylogeny of parasitic Platyhelminthes: a critical study of synapomorphies proposed on the basis of the ultrastructure of spermiogenesis and spermatozoa. Can. J. Zool. 69: 1421-1440.

Justine J.-L. 1998: Spermatozoa as phylogenetic characters for the Eucestoda. J. Parasitol. 84: 385-408.

Justine J.-L. 2001: Spermatozoa as phylogenetic characters for the Platyhelminthes. In: D.T.J. Littlewood and R.A. Bray (Eds.), 
Interrelationships of the Platyhelminthes. Taylor and Francis, London, pp. 231-238.

Levron C., Bruñanská M., Kuchta R., Freeman M., Scholz T. 2006c: Spermatozoon ultrastructure of the pseudophyllidean cestode Paraechinophallus japonicus, a parasite of deep-sea fish Psenopsis anomala (Perciformes, Centrolophidae). Parasitol. Res. 100: 115-121.

Levron C., Bruñanská M., Marchand B. 2005: Spermiogenesis and sperm ultrastructure of the pseudophyllidean cestode Triaenophorus nodulosus (Pallas, 1781). Parasitol. Res. 98: 26-33.

Levron C., Bruñanská M., Poddubnaya L.G. 2006a: Spermatological characters in Diphyllobothrium latum (Cestoda, Pseudophyllidea). J. Morphol. 267: 1110-1119.

Levron C., Bruñanská M., Poddubnaya L.G. 2006b: Spermatological characters of the pseudophyllidean cestode Bothriocephalus scorpii (Muller, 1781). Parasitol. Int. 55: 113-120.

Levron C., Miquel J., Oros M., Scholz T. 2010: Spermatozoa of tapeworms (Platyhelminthes, Eucestoda): advances in ultrastructural and phylogenetic studies. Biol. Rev. 85: 523-543.

Levron C., Sitko J., Scholz T. 2009: Spermiogenesis and spermatozoon of the tapeworm Ligula intestinalis (Diphyllobothriidea): phylogenetic implications. J. Parasitol. 95: 1-9.

Mahendrasingam S., Fairweather I., Halton D.W. 1989: Spermatogenesis and the fine structure of the mature spermatozoon in the free proglottis of Trilocularia acanthiaevulgaris (Cestoda, Tetraphyllidea). Parasitol. Res. 75: 287-298.

McKerr G. 1985: The fine structure and physiology of a trypanorhynch tapeworm Grillotia erinaceus. Unpublished $\mathrm{PhD}$ thesis, The Queen's University of Belfast.

Miquel J., Eira C., Świderski Z., Conn D.B. 2007b: Mesocestoides lineatus (Goeze, 1782) (Mesocestoididae): new data on sperm ultrastructure. J. Parasitol. 93: 545-552.

Miquel J., Feliu C., Marchand B. 1999: Ultrastructure of spermiogenesis and the spermatozoon of Mesocestoides litteratus (Cestoda, Mesocestoididae). Int. J. Parasitol. 29: 499-510.

Miquel J., Foronda P., Torres J., Świderski Z., Feliu C. 2009: Ultrastructural study of the spermatozoon of Taenia taeniaeformis (Batsch, 1786) (Cestoda, Cyclophyllidea, Taeniidae), an intestinal parasite of Felis catus from La Palma (Canary Islands, Spain). Parasitol. Res. 104: 1477-1483.

Miquel J., Fournier-Chambrillon C., Fournier P., Torres J. 2006: Spermiogenesis and spermatozoon ultrastructure of the cranial digenean Troglotrema acutum (Leuckart, 1842). J. Parasitol. 92: 441-453.

Miquel J., Marchand B. 1998: Ultrastructure of spermiogenesis and the spermatozoon of Anoplocephaloides dentata (Cestoda, Cyclophyllidea, Anoplocephalidae), an intestinal parasite of Arvicolidae rodents. J. Parasitol. 84: 1128-1136.

Miquel J., Świderski Z. 2006: Ultrastructure of the spermatozoon of Dollfusiella spinulifera (Beveridge and Jones, 2000) Beveridge, Neifar and Euzet, 2004 (Trypanorhyncha, Eutetrarhynchidae). Parasitol. Res. 99: 37-44.

Miquel J., Świderski Z., Mackiewicz J.S., Ibraheem M.H. 2008: Ultrastructure of spermiogenesis in the caryophyllidean cestode Wenyonia virilis (Woodland, 1923) with re-assessment of flagellar rotation in Glaridacris catostomi (Cooper, 1920). Acta Parasitol. 53: 19-29.

Miquel J., Świderski Z., Neifar L., Eira C. 2007a. Ultrastructure of the spermatozoon of Parachristianella trygonis Dollfus, 1946 (Trypanorhyncha, Eutetrarhynchidae). J. Parasitol. 93: 1296-1302.

Miquel J., Torres J., Foronda P., Feliu C. 2010: Spermiogenesis and spermatozoon ultrastructure of the davaineid cestode

Received 10 June 2010
Raillietina micracantha (Fuhrmann, 1909). Acta Zool. (Stockh.) 91: 212-221.

Mokhtar-Maamouri F. 1979: Étude en microscopie électronique de la spermiogenèse et du spermatozoïde de Phyllobothrium gracile Weld, 1855 (Cestoda, Tetraphyllidea, Phyllobothriidae). Z. Parasitenkd. 59: 245-258.

Mokhtar-MaAmouri F. 1982: Étude ultrastructurale de la spermiogenèse de Acanthobothrium filicolle var. filicolle Zschokke, 1888 (Cestoda, Tetraphyllidea, Onchobothriidae). Ann. Parasitol. (Paris) 57: 429-442.

Mokhtar-Maamouri F., Świderski Z. 1975: Étude en microscopie électronique de la spermatogénèse de deux Cestodes Acanthobothrium filicolle benedenii Loennberg, 1889 et Onchobothrium uncinatum (Rud., 1819) (Tetraphyllidea, Onchobothriidae). Z. Parasitenkd. 47: 269-281.

Mokhtar-Maamouri F., Świderski Z. 1976: Ultrastructure du spermatozoïde d'un Cestode Tetraphyllidea Phyllobothriidae, Echeneibothrium beauchampi Euzet, 1959. Ann. Parasitol. (Paris) 51: 673-674.

Noever C., Caira J.N., Kuchta R., Desjardins L. 2010: Two new species of Aporhynchus (Cestoda: Trypanorhyncha) from deep water lanternsharks (Squaliformes: Etmopteridae) in the Azores, Portugal. J. Parasitol. 96: 1176-1184.

Olson P.D., Littlewood D.T.J., Bray R.A., Mariaux J. 2001: Interrelationships and evolution of the tapeworms (Platyhelminthes: Cestoda). Mol. Phylogenet. Evol. 19: 443-467.

PALm H.W. 2004: The Trypanorhyncha Diesing, 1863. PKSPL-IPB Press, Bogor, $710 \mathrm{pp}$.

Palm H.W., Waeschenbach A., Olson P.D., Littlewood D.T.J. 2009: Molecular phylogeny and evolution of the Trypanorhyncha Diesing, 1863 (Platyhelminthes: Cestoda). Mol. Phylogenet. Evol. 52: 351-367.

Quilichini Y., Foata J., Justine J.-L., Bray R.A., Marchand B. 2010: Spermatozoon ultrastructure of Aponurus laguncula (Digenea: Lecithasteridae), a parasite of Aluterus monoceros (Pisces, Teleostei). Parasitol. Int. 59: 22-28.

Reynolds E.S. 1963: The use of lead citrate at high $\mathrm{pH}$ as an electron-opaque stain in electron microscopy. J. Cell Biol. 17: 208-212.

Sène A., BÂ C.T., Marchand B. 1997: Ultrastructure of spermiogenesis and the spermatozoon of Nomimoscolex sp. (Cestoda, Proteocephalidea) intestinal parasite of Clarotes laticeps (Fish, Teleost) in Senegal. J. Submicrosc. Cytol. Pathol. 29: 1-6.

Š́ípová L., Levron C., Freeman M., Scholz T. 2010: Spermiogenesis and spermatozoon of the tapeworm Parabothriocephalus gracilis (Bothriocephalidea): Ultrastructural and cytochemical studies. Acta Parasitol. 55: 58-65.

ŚWIDERSKI Z. 1976: Fine structure of the spermatozoon of Lacistorhynchus tenuis (Cestoda, Trypanorhyncha). Proc. 6th Eur. Congr. Electron Microsc., Jerusalem, pp. 309-310.

ŚWIDERSKi Z. 1986: Three types of spermiogenesis in cestodes. Proc. 11th Int. Congr. Electron Microsc., Kyoto, pp. 2959-2960.

ŚWIDERSKi Z. 1994: Spermiogenesis in the Trypanorhynchid cestode Lacistorhynchus tenuis. Proc. 13th Int. Congr. Electron Microsc., Paris, pp. 691-692.

Świdersiri Z., Mokhtar-MaAmouri F. 1980: Étude de la spermatogénèse de Bothriocephalus clavibothrium Ariola, 1899 (Cestoda: Pseudophyllidea). Arch. Inst. Pasteur Tunis 57: 323-347.

THiéry J.P. 1967: Mise en évidence des polysaccharides sur coupes fines en microscopie électronique. J. Microsc. 6: 987-1018. 